\title{
THE PREVALENCE OF CONGENITAL HEART DISEASES AMONG ROMANIAN CHILDREN - EXPERIENCE OF A SINGLE CENTER
}

\author{
Hrusca Adrian ${ }^{1}$, Rachisan Andreea Liana ${ }^{1}$, Chira Emanuel ${ }^{2}$, Oprita Simona ${ }^{2}$, Andreica Mariana ${ }^{1}$, Cainap Simona ${ }^{1}$
}

Aim. Congenital heart defects (CHD) are the leading cause of infant mortality becoming an important public health problem. Time trends in CHD by specific phenotype and with long follow-up time are rarely available for a large pediatric population.

Material and methods. We present the prevalence of $\mathrm{CHD}$ over the past 5 years among Romanian children. Individuals with CHDs were classified by several criteria including type of pathology, association of the pathology with various syndromes and abnormalities, postnatal complications or treatment.

Results. The overall CHD birth prevalence increased. Generally, prevalence increased for defects diagnosed in infancy and preschoolers patients. Isolated septal defects such as atrial septal defect (ASD) was present in $29,69 \%$ of patients while transposition of the great vessels was present in $1,87 \%$ of children, respectively. Among the severe defects, tetralogy of Fallot - atresia/hypoplasia of the pulmonary artery association showed the largest prevalence. Considering the syndromatic CHD, the highest incidence $(78,78 \%)$ was recorded for Down syndrome, followed by Turner syndrome. The most frequent postnatal complication in CHD patients was cardiomegaly, followed by pulmonary hypertension. Only $29,94 \%$ of the patients underwent corrective surgery, the rest remained on medication. The highest incidence rate was recorded for tetralogy of Fallot $(42,85 \%)$, followed by isolated septal defects. On average, tetralogy of Fallot cases were operated on 16,6 months after diagnosis while transposition of the great vessels after 2,5 months.

Conclusion. The increasing prevalence of CHDs reported was confirmed in the present study. This is mostly due to an increasing number of isolated septal defects diagnosed in infancy. In the future, the etiology of $\mathrm{CHD}$ needs to be further clarified and prospective birth defect registries covering the a large population are needed to determine the exact birth prevalence of $\mathrm{CHD}$.

Russ J Cardiol 2014, 7 (111), Engl.: 47-50

Key words: congenital heart disease, prevalence, children, syndrome, pregnancy.

'University of Medicine \& Pharmacy "Iuliu Hatieganu", Department of Pediatrics II, Cluj-Napoca; ${ }^{2}$ University of Medicine \& Pharmacy "Iuliu Hatieganu", Hospital of Cardiovascular Surgery, Cluj-Napoca, Romania.

Corresponding author. Andreea Liana Rachisan, University of Medicine \& Pharmacy "Iuliu Hatieganu" Cluj-Napoca, Romania. 3-5 Crisan Street, Cluj-Napoca 400371, Romania. Tel: 0040-755-511115; e-mail: andreea rachisan@yahoo.com

ASD - atrial septum defect, CHD - congenital heart diseases, VSD - ventricular septum defect, GUCH - grown-up congenital heart disease.

Hrusca Adrian - Teaching Assistant, Rachisan Andreea Liana - Teaching Assistant Chira Emanuel - Medical Doctor, Oprita Simona - Medical Doctor, Andreica Mariana - Professor, Cainap Simona - Teaching assistant.

Received August 01, 2014.

Revision received August 08, 2014.

Accepted August 15, 2014.

\section{РАСПРОСТРАНЕННОСТЬ ВРОЖДЕННЫХ ПОРОКОВ СЕРДЦА СРЕДИ РУМЫНСКИХ ДЕТЕЙ - ОПЫТ ОДНОГО ЦЕНТРА}

\author{
Hrusca Adrian ${ }^{1}$, Rachisan Andreea Liana ${ }^{1}$, Chira Emanuel ${ }^{2}$, Oprita Simona ${ }^{2}$, Andreica Mariana ${ }^{1}$, Cainap Simona ${ }^{1}$
}

Цель. Врожденные пороки сердца (CHD), являющиеся ведущей причиной младенческой смертности, становятся важной проблемой общественного здравоохранения. Тенденцией последнего времени в области диагностики CHD направлены на конкретный фенотип и по причине длительного времени наблюдения редко бывают доступны для большей части детского населения.

Материал и методы. Мы представляем распространенность CHD за последние 5 лет среди румынских детей. Лица с CHD были классифицированы по нескольким критериям, в том числе вида патологии, ассоциации патологии с различными синдромами и аномалиями, послеродовыми осложнениями или лечением.

Результаты. Общее количество CHD при рождении увеличилось. В целом, увеличилось распространенность диагностирование пороков у младенцев и дошкольников. Изолированные септальные пороки, такие как дефект межпредсердной перегородки (ASD) присутствовали у 29,69\% пациентов, тогда как транспозиция магистральных сосудов присутствовала у 1,87\% детей, соответственно. Среди серьезных дефектов, тетрада Фалло - ассоциация атрезия/гипоплазия легочной артерии проявила наибольшую распространенность. Учитывая симптоматические CHD, наиболее высокий уровень заболеваемости $(78,78 \%)$ был отмечен для синдрома Дауна, сопровождаемого синдромом Тернера. Из наиболее частых послеродовых осложнений у больных CHD наблюдалась кардиомегалия, затем легочная гипертензия. Только 29,94\% пациентов, были подвергнуты хирургическим операциям, остальные оставались на лекарственной терапии. Наивысший уровень заболеваемости был отмечен при тетраде Фалло (42,85\%), а также изолированных септальных пороках. В среднем, больные с тетрадой Фалло были прооперированы через 16,6 месяцев после установления диагноза, в то время как с транспозицией магистральных сосудов через 2,5 месяцев.

Заключение. Сообщение о растущем преобладании CHD было подтверждено в настоящем исследовании. Это произошло, в основном, за счет увеличения количества изолированных септальных дефектов, диагностируемых в младенчестве. В будущем, этиология CHD нуждается в дальнейшем уточнении и создание перспективных реестров дефектов при рождении, охватывающих большие группы населения, необходимо для определения точной распространенности CHD.

Российский кардиологическийй журнал 2014, 7 (111), Англ.: 47-50

Ключевые слова: врожденный порок сердца, распространенность, дети, синдром, беременность.

'University of Medicine \& Pharmacy "Iuliu Hatieganu", Department of Pediatrics II Cluj-Napoca; 'University of Medicine \& Pharmacy "Iuliu Hatieganu", Hospital of Cardiovascular Surgery, Cluj-Napoca, Румыния. 


\section{Introduction}

Congenital heart diseases (CHD) are the most common cause of congenital anomalies being an increasing health problem. Twenty-eight percent of all major congenital anomalies consist of heart defects [1]. CHD comprises a wide range of cardiovascular malformations from critical forms presenting in the immediate newborn period to mild defects which may not be detected until adulthood [2]. The birth prevalence of CHD is estimated to 8 per 1,000 live births [3]. Nowadays, the cardiovascular diagnostics and cardiothoracic surgery have improved, leading to an increased survival of newborns with CHD. Thus, a lot of patients with $\mathrm{CHD}$ reach adulthood. The prevalence of CHD is estimated to be 4 per 1,000 adults [4], the number of adults with CHD exceeding the number of affected children [5]. Despite remarkable progress in the clinical care there are major challenges regarding the management of CHD, which remains the leading cause of infant mortality among birth defects [6]. In our study, we aimed to evaluate the prevalence of CHD in Romanian children admitted in our hospital.

\section{Material and methods}

We carried out a descriptive study over a period of five years (2007-2012) on patients admitted in the Department of Pediatrics II Cluj-Napoca, Romania. We enrolled 266 children diagnosed with congenital heart defects based on their echocardiographic examination. The inclusion criteria were the maximum age of 18 years at the diagnostic and the need for corrective surgery.

The following data was taken into account: type of pathology, association of the pathology with various syndromes and abnormalities, postnatal complications or treatment.

The study was approved by the local Committee of Ethics of the University of Medicine and Pharmacy of Cluj-Napoca. Informed consent was obtained from parents or legal tutors at the moment of admission to hospital in compliance with the principles of the Helsinki Declaration.

Statistical analysis was performed using Statistical Package for Social Sciences (SPSS) 21.0 for Windows for a descriptive analysis of the population. Results were expressed as means \pm standard deviations.

\section{Results}

Mean patients age was $3,66 \pm 4,60$ years (male: female $=151: 115)$. The following age groups are taken into account:

- 0-1 month: newborn (27 patients)

- 1-12 months: infant (92 patients)

- 12 months - 36 months: toddler (37 patients)

- 36 months -72 months: preschooler (45 patients)

- 72 moths - 120 months: older child (39 patients)

- 120 moths -168 months: puberty (13 patients)

- >168 months: adolescence (13 patients).

\section{Types of congenital heart defects}

\begin{tabular}{|l|l|}
\hline Type of defect & Number \\
\hline Atrial septum defect & 79 \\
\hline Ventricular septum defect & 40 \\
\hline Tetralogy of Fallot & 30 \\
\hline Patent ductus arteriosus & 27 \\
\hline Valvular defects & 40 \\
\hline Common atrioventricular canal & 14 \\
\hline Coarctation of the aorta & 10 \\
\hline Transposition of the great vessels & 5 \\
\hline Others & 21 \\
\hline
\end{tabular}

$78,19 \%$ (208) mothers had a normal evolution of the pregnancy, whereas $21.80 \%$ (58) had coexisting conditions or abnormalities. The main events that caused the abnormal progression of this pregnancies were divided into: particular situations (gemellary pregnancy $21 \%$, in vitro fertilization $8 \%$ ); abnormal pregnancy (placenta praevia $8 \%$, oligo and polyhydramnios $5 \%$, gestational diabetes $5 \%$, pre-eclampsia $31 \%$ ); incidents during pregnancy (imminent abortion, abdominal pains and bleeding $32 \%$ ). We note that 204 of the deliveries were spontaneous and that 62 were C-sections. $84,96 \%$ (226) of the deliveries were on due date whereas 40 were preterm deliveries.

The most frequently encountered types of CHD are listed in Table 1. The most frequent CHD was atrial septum defect (ASD) present in $29,69 \%$ of patients while transposition of the great vessels was present in 1,87\% of children. $33,08 \%$ of patients with confirmed CHD suffer from complex heart defects. The most frequent association is the one between bicuspid aortic valve and stenosis or aortic regurgitation (12 patients, 13,63\%), followed by the atrial septal defect patent ductus arteriosus ( 9 patients, 10,22\%) and the ventricular septal defect - tricuspidic regurgitation associations 9 patients, 10,22\%). Eight patients $(9,09 \%)$ suffer from the tetralogy of Fallot - atresia/hypoplasia of the pulmonary artery association. The rarest association is the one between ventricular septal defect and coarctation of the aorta, association encountered in only 1 patient.

$87,60 \%$ (233) patients included in the group under study do not suffer from chromozome abnormalities, whereas $12.40 \%$ (33) of these patients do suffer from this type of pathology. The highest incidence $(78,78 \%)$ is recorded for Down syndrome, which affects 26 children, followed by Turner syndrome.

The most frequent postnatal complication in CHD patients was cardiomegaly, followed by pulmonary hypertension (Figure 1).

$29,94 \%$ of the patients underwent corrective surgery, the rest remained on medication. The highest incidence rate is recorded for tetralogy of Fallot $(42,85 \%)$, followed by atrial septal defect and ventricular septal defect 
(37,68\%), the coarctation of the aorta $12,98 \%$ and transposition of the great vessels $(6,49 \%)$.

The highest number of surgeries was performed on toddlers, preschoolers and infants. The fewest surgeries were recorded children having reached puberty (Figure 2).

On average, tetralogy of Fallot cases were operated on 16,6 months after diagnosis. This condition is followed by the atrial septal defect (10,5 months), ventricular atrial defect (10 months), common atrioventricular canal (6 months), patent ductus arteriosus (4 months) and transposition of the great vessels (2,5 months).

\section{Discussion}

We determined the beginning and the incidence of the pathology, as well as its association with other syndromes and defects. We analyzed symptomatology and gathered data on the age at which the congenital heart defects were diagnosed, as well as other data regarding the optimal age for performing surgical treatment, therapeutic attitude and results obtained.

Over the decades the prevalence of CHD birth increased substantially, from 1 per 1,000 live births in 1930 to 9 per 1,000 live births in recent years [7]. The rise in observed prevalence of CHD is likely multifactorial. This may be caused by changes in diagnostic methods and screening modalities rather than a true increase. Specialized pediatric cardiologists are being trained and the screening for CHD became an important step before noncardiac surgery causing an increase in diagnoses of minor lesions such as a small ventricular septum defect (VSD) or ASD. Survival of premature infants has improved over the last century, attributing to an increase in total CHD and especially VSD birth prevalence [6].

In addition, the patient population with $\mathrm{GUCH}$ is steadily increasing and their offspring is at increased risk of having a congenital abnormality [8]. Furthermore, factors such as maternal pre-gestational diabetes mellitus, phenylketonuria, infections, various therapeutic drug exposures, vitamin A use, have been proven to be associated with increased risk of CHD [9]. The impact of increased use of fetal echocardiography and pregnancy termination on reduction of CHD birth prevalence is expected in the next time periods [10].

One reason could be that the classification of CHDs is challenging because of the wide range of known defects, with different underlying etiologies for each class of defects.

Congenital heart defects include a range of defects that, according to errors in specific sequences of cardiac development can be broadly be classified [11]. Various heart malformations may occur in combination or, as single defects. However, an increase in prevalence due to improved diagnostics may also have been counteracted by increased prenatal screening for congenital malformations and subsequent termination of affected pregnancies. In the present study, the prevalence of severe CHDs overall and by specific defect corresponded well with estimates from comparable population-based registers [12].

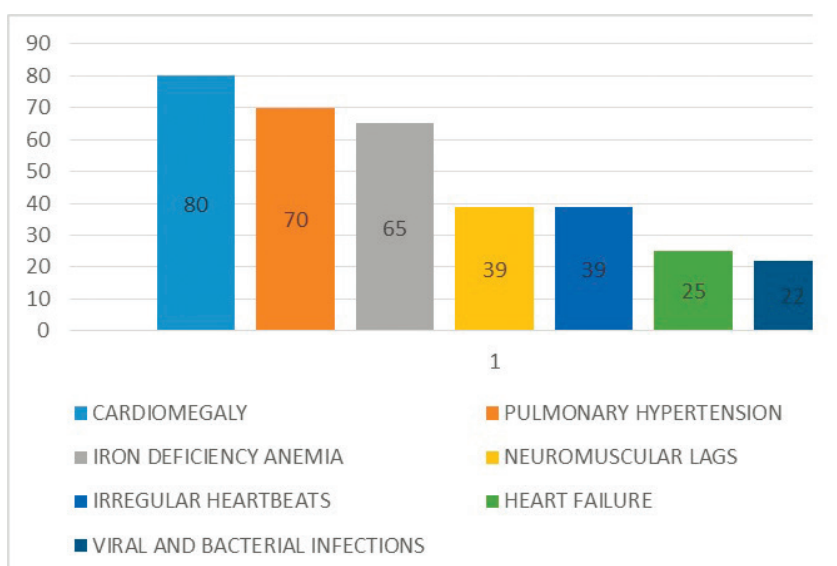

Fig. 1. The histogram showing the postnatal complications in CHD patients.

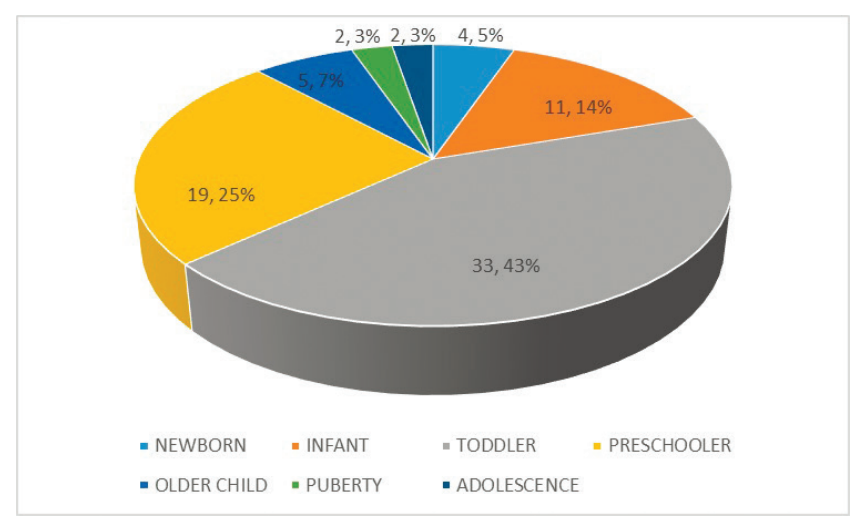

Fig. 2. The scatter-plot showing the age groups.

For some time, the pathogenesis of CHD has been attributed to genetic and environmental factors, including possible interactions between them. The epidemiological evidence strongly points to genetic factors playing a crucial role in the pathogenesis of CHD. The causes of CHD remain largely unknown. Aneuploidies such as trisomy 21 (causing Down syndrome) are strongly associated with CHD. Using technologies that detect copy number variants has uncovered numerous other segmental aneuploidies that cause CHD [13]. However, genetic factors underlying CHD largely remain to be elucidated. This is due to the challenges associated with that pathology.

The increasing prevalence of CHDs reported was confirmed in the present study. This is mostly due to an increasing number of isolated septal defects diagnosed in infancy, although we also found that severe defects contributed to the increase in CHD prevalence. It remains uncertain whether detected differences in CHD birth prevalence represent true or merely methodological differences.

In the future, the etiology of CHD needs to be further clarified and population wide prospective birth defect registries covering the entire world population are needed to determine the exact birth prevalence. These data have been important in generating interest in adult CHD as a new subspecialty of cardiology. 


\section{References}

1. Dolk H, Loane M, Garne E, for the European Surveillance of Congenital Anomalies (EUROCAT) Working Group. Congenital heart defects in Europe: prevalence and perinatal mortality, 2000 to 2005. Circulation 2011; 123:841-9.

2. Tennant PW, Pearce MS, Bythell M, Rankin J. 20-year survival of children born with congenital anomalies: a population-based study. Lancet 2010; 375:649-56.

3. Bernier PL, Stefanescu A, Samoukovic G, Tchervenkov Cl. The challenge of congenital heart disease worldwide: epidemiologic and demographic facts. Semin Thorac Cardiovasc Surg Pediatr Card Surg Annu 2010; 13:26-34.

4. Khairy P, lonescu-Ittu R, Mackie AS, et al. Changing mortality in congenital heart disease. J Am Coll Cardiol 2010; 56:1149-57.

5. Williams RG, Pearson GD, Barst RJ, et al. National Heart, Lung, and Blood Institute Working Group on research in adult congenital heart disease. Report of the National Heart, Lung, and Blood Institute Working Group on research in adult congenital heart disease. J Am Coll Cardiol. 2006; 47:701-7.

6. Yang $\mathrm{Q}, \mathrm{Chen} \mathrm{H}$, Correa $\mathrm{A}$, et al. Racial differences in infant mortality attributable to birth defects in the United States, 1989-2002. Birth Defects Res Part A Clin Mol Teratol. 2006; 76:706-13
7. Hoffman Jl. Incidence of congenital heart disease: I. Postnatal incidence. Pediatr Cardiol 1995; 16:103-13.

8. Van der Bom $\mathrm{T}$, Zomer AC, Zwinderman $\mathrm{AH}$, et al. The changing epidemiology of congenital heart disease. Nat Rev Cardiol 2011; 8:50-60.

9. Jenkins KJ, Correa A, Feinstein JA, et al. Noninherited risk factors andcongenital cardiovascular defects: current knowledge: a scientific statement from the American Heart Association Council on Cardiovascular Disease in the Young: endorsed by the American Academy of Pediatrics. Circulation 2007; 115:2995-3014.

10. Germanakis I, Sifakis S. The impact of fetal echocardiography on theprevalence of liveborn congenital heart disease. Pediatr Cardiol 2006; 27:465-72.

11. Kirby ML. Cardiac development. Oxford: Oxford University Press; 2007.

12. International Clearinghouse for Birth Defects. Surveillance and research. Available at: http://www.icbdsr.org.

13. Hitz MP, Lemieux-Perreault LP, Marshall C, et al. Rare copy number variants contribute to congenital left-sided heart disease. PLoS Genet. 2012. 